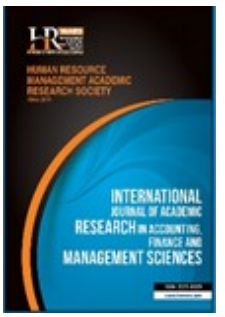

International Journal of Academic Research in Accounting, Finance and Management Sciences

Vol. 9, No.3, July 2019, pp. 17-23

E-ISSN: 2225-8329, P-ISSN: 2308-0337

(c) 2019 HRMARS

www.hrmars.com

To cite this article: Bani-Khalid, T.O. (2019). Corporate Sustainability Reporting: A longitudinal Analysis of its Evolutionary Pattern, International Journal of Academic Research in Accounting, Finance and Management Sciences 9 (3): 17-23

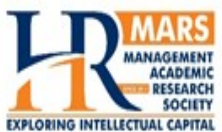

\title{
Corporate Sustainability Reporting: A longitudinal Analysis of its Evolutionary Pattern
}

\author{
Tareq O Bani-Khalid \\ Accounting Department - Faculty of Economics \& Administrative Science, Al al-Bayt University, Mafraq, Jordan, \\ Email: tareq_alkhaldi@aabu.edu.jo
}

\begin{abstract}
The aim of the paper is to longitudinally trace the evolutionary path of conceptual framework on corporate sustainability performance to provide a clear understanding of how integrating environmental, social and economic organisation's responsibility with each other. It is also aims to provide a clearer vision as to how an organisations should inform stakeholders of their strategies and responsibilities, and of how they are dealing with the sustainability implications of their activities. Using longitudinal analysis of the relevant literature on corporate sustainability reporting, the paper concluded that the conceptual shift of corporate sustainability has passed through three different stages during the past decades. 1950's-1970s has viewed as the first conceptual shift of corporate sustainability concept. This concept was referred to as voluntary initiatives and ethical responsibility that were focused on how to protect present and future generations' rights and their natural environment. The second conceptual shift with respect to corporate sustainability concept was appeared between 1980s -1990s as the beginning of modern era of global sustainability. This era marked with coalitions of international organisations to promote global acceptance of sustainability concept within business practices. While, the 2000s was seen as an era of corporate transparency on sustainability issues; the paper also found a great shift in focus throughout the recent years to expand the corporate sustainability communication with unlimited number of potential and existing stakeholders.
\end{abstract}

Key words Sustainability, Sustainable Development, Corporate Sustainability Practices, Sustainability Reporting

Received: 28 Aug 2019 (C) The Authors 2019

Revised: 09 Sept 2019 Published by Human Resource Management Academic Research Society (www.hrmars.com)

Accepted: 12 Sept 2019 This article is published under the Creative Commons Attribution (CC BY 4.0) license. Anyone may Published Online: 29 Sept 2019 reproduce, distribute, translate and create derivative works of this article (for both commercial and non-commercial purposes), subject to full attribution to the original publication and authors. The full terms of this license may be seen at: http://creativecommons.org/licences/by/4.0/legalcode

\section{Introduction}

Amid growing public concerns about the detrimental impacts of the Second World War, it has been argued that:."Warfare is inherently destructive of sustainable development. States shall therefore respect international law providing protection for the environment in times of armed conflict \& cooperate in its further development, as necessary" (Rio Declaration on Environment \& Sustainable Development, Principle 24).

Although the above principle was written about 30 years ago, however, it supports the argument by United Nations that there is an urgent need to introduce a theoretical framework to integrate all needs of the present and future generations in one comprehensive concept. Indeed, such growing needs has given rise to the concept of Sustainable Development (SD), which has rapidly growing and becoming a global trend in the last decades (United Nations, 1987). Thus, it is important to explain the evolutionary path of the sustainable development concept and its role in maintaining a balance on the economic, 
environmental, and societal aspects which eventually affect human life in all their forms; therefore, looking at the historic development of this global term is important. However, it might be interesting to provide a first look into this evolution throughout in below figure.1 for the phases of acceptance of corporate sustainability and its reports before discussing it in the next sub-sections.

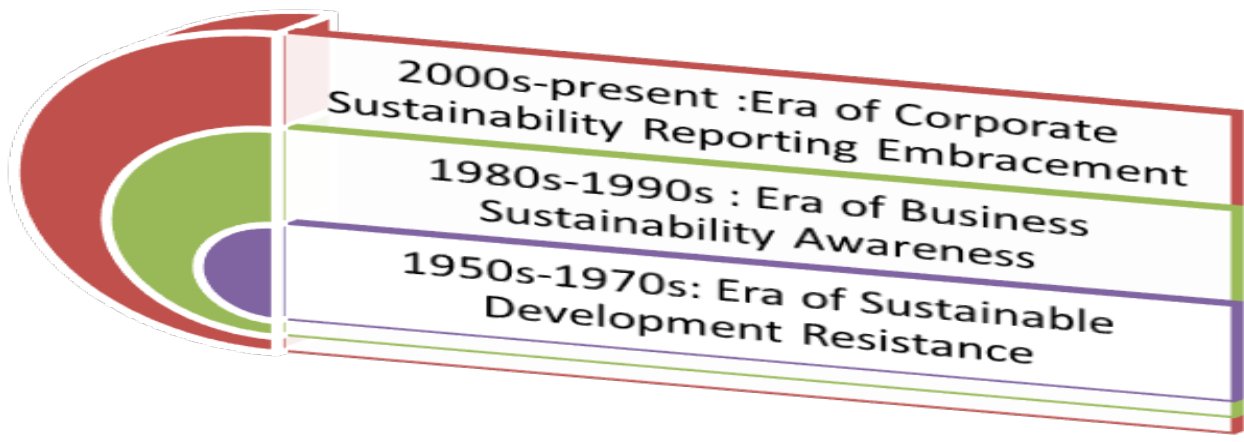

Figure 1. Historical development of the concept of corporate sustainability reporting.

Therefore, based on the discussion above, the study is structured such that the current section (1) introduction of the study; next section (2) deals with the evolutionary path of corporate sustainability and its reports, which is classified into four eras; while the last section (3) concludes the study.

\section{Literature Review}

\subsection{Era of Sustainable Development Resistance (1950 - 1970)}

According to Du-Pisani (2006), the emergence of the idea of sustainable development was linked with the collapse of major colonial powers and the military alliances during the Mid-20th century. During that period, many countries of this world, in Asia, Europe and Africa, have witnessed great conflicts during that time to control their wealth and power as an importance capital asset that might support the war alliances. Consistent with this argument, it is opined by Harris (2000), that Sustainability, as a new concept in the business literature, is gradually crystallized by the end of the Second World War, especially when its noticed that humans in their way to destroy their planet and its natural environment.

In the late 1960s, there were many negative images that embodied human's unethical actions in the depletion of their natural resources and environmental degradation (Rezaee, 2016). The destruction of forests for building ships, fires, and using a chemical weapons, fuel consumption, water pollution, poverty and spread diseases are all realistic examples for the World War II in destroying the environment and society (Rezaee 2016; Du-Pisani, 2006).

Increased potential negative consequences of the human activities on worlds' natural resources were perceived as motives for defining sustainability concept. In fact, such growing concerns drew public's attention to argue that all human generations whether current or future generations have the full right to use and conservation of natural resources in a balanced and fair manner (WECD, 1987; Erekson et al. 1999). It was argued that this way of thinking in favour of the responsible use of natural resources and protecting the rights for future generations has helped the emergence of the concept of sustainable development as a western phenomenon in the business literature in the mid-1970s (Paul, 2008; Du-Pisani, 2006). In particular, it's argued that "sustainable development policies look to tackle the sources of environmental degradation, while still providing opportunities and creating incentives for economic advancement" (Porter and Linde, 1995). Furthermore, in their work (Campopiano et al., 2012) suggested that in addition to this way of thinking towards the human generations' rights, (i) Global rapid responses to urgent non-financial issues; (ii) along with increasing demand on natural resources driven by increasing rate of world population growth have also identified as common drivers for adoption of sustainability as a green economy concept in early of 1970s (Hackston and Milne, 1996).

In this regard, IISD (2012) reported that, the 1970s decades was the starting point for the Green Movement, which was represented in many initiatives such as Greenpeace and Friends of the Earth, and Green Political Party. In particular, this decade saw further expansion of the conceptual awareness of SD in the international forums. One of the most important contributions to the concept of SD during this decade 
was made by Gaylord Nelson in the United States, when he argued that, nowadays (1970s), there are more opportunities to provide unity to the grassroots environmental movement and increase public awareness. Proceeding from Gaylord's argument, earth-day was the first global event, that held on 22, 1970, to celebrate the planet's environment and raise public awareness about pollution. Canada also has contributed in the consolidation of environmental awareness and sustainability concepts by issuing strict instructions to stop environmental damage through employing peaceful protests methods to achieve this goal in 1971. In the same year, 1971, Switzerland also provided an integrated report aims to provide an insight about the integration of environment and development strategies, followed by the UK by establishing the International Institute for Environment \& Development (IIED), which aims to make economic progress without destroying the environmental resource base. Human Environment Conference that held in Stockholm in 1972, which focused in its dialogue on the importance of protecting earth's natural resources (water, air and soil), and respect all internationally proclaimed environmental rights of northern Europe. By the end of 1970s, World-watch Institute has been also established in the U.S. in order to raise public awareness of global environmental threats and catalyse effective policy responses (IISD, 2012).

\subsection{Era of Business Sustainability Awareness (1980 -1990)}

In the 1980s decade, the concept of Corporate Sustainability (CS) has become a global buzzword, which used as a common phrase when referring to engage in more socio-environmental practice within the business operations (Anderies et al., 2013; Fisher and Rucki, 2016). More specifically, it has become increasingly important in all business studies as the 1980s decade saw a number of ethical scandals in the corporate world. These include for example, the Union Carbide chemical leak in Bhopal India in 1984; the Chernobyl disaster in 1986; and Exxon Valdez oil spill in Alaska in 1989, which have been played crucial role in the proliferation of today's SD strategy as a relatively new concept in the literature on accounting (Gray \& Bebbington, 2001). Therefore, this decade might be called as a period of public intellectual maturity towards the strategy of CS (Du-Pisani, 2006). In this regard, Gudmundsson et al. (2016) argued that CS in the1980s "has garnered much interest from government agencies, businesses, non-government organizations, and civic groups").

Additionally, in the1987, World Commission on Environment and Development (WECD) has played a significant role in contributing the concept of sustainability (Jenkins and Yakoleva, 2006). The WECD has focused upon the need to understand the human ability to maintain the quality of life on our environment. This is was by enhancing creativity thinking of human mind about the importance of meeting "the needs of the present without compromising the ability of future generations to meet their own needs?" (WCED, 1987). As such, many corporate businesses are today not only paying attention to the financial needs of their stakeholders, but they have to contend serve constructively all the needs of the stakeholder to the satisfaction of the society" (CED, 1971).

It noted that the social contract between business and surrounding environment was changing in considerable and important ways: "Business is being asked to assume broader responsibilities to society than ever before and to serve a wider range of human values. Business enterprises, in effect, are being asked to contribute more to the quality of [human] life than just supplying goods and services. In as much as business exists to serve society, its future will depend on the quality of management's response to the changing expectations of the public" (CED, 1971).

From the above quotation, it could be noted that there was a remarkable shift in public perceptions towards the conceptual basis of SD. This remarkable shift in public awareness was concentrated towards how to link more aspects of corporate sustainability. In this regard Hopwood et al. (2005) have provided a new paradigm linking corporate socio-environmental concerns to their economic development to mitigate their negative effects. This linking implies that accomplishing corporate sustainability involves finding the right balance for each of the three categories (Pearce, 1999).

1990s was referred to as the beginning of modern history of global sustainability (O'Dwyer et al., 2005). This decade marked with enactment of numerous globe protocols to regulate conduct of businesses within basic rules of conservation of natural resources for future generations (IISD, 2012). The UN Conference on the Environment and Development (UNCED), which was held in Rio de-Janeiro, Brazil, 1992, 
was the biggest historical event concerning to the SD with the largest gathering of 114 heads of state, and 1400 representatives from more than 175 international organizations (Paul, 2008). The International Institute for Sustainable Development (IISD) and the Regional Environmental Centre for Central and Eastern Europe (RECCEE) were also established, during the 1990s, as global environmental agencies that have a tendency to focus on the engagement of businesses with their surrounding environment. In the 1995, World Trade Organization (WTO) was established also in order to increase the formal recognition of trade, environment and development linkages. One year after the WTO's establishment, ISO 14001 is formally adopted as a voluntary international Initiative for corporate environmental management.

\subsection{Era of Corporate Sustainability Reporting Embracement (2000-Present)}

The year 2000 to present is regarded as the new golden age of transparency and the expansion of corporate sustainability reporting literature (Meyer and Kirby, 2010). This decade saw expansion of public awareness about the importance of sustainability information in encouraging further recognition of the other stakeholder demands (Deana, 2002); thus, legitimating corporate business practices (Roberts and Joplin, 2007). Given that companies recognize their accountability to a broad group of stakeholders" (Adams and Forts, 2006), therefore, they would need to make further efforts to inform stakeholders about their non-financial strategies by using any form of communication (Gray et al., 1995).

In its broadest sense, corporate reports are the most common source use to meet the stakeholders' expectation regarding the sustainability practices (Deegan \& Rankin, 1996; O'Dwyer et al. 2005). However, it is also argued that corporate reporting through their annual reports or through separate reports is traditional function, and meets only the needs of a limited number of stakeholders (Gray et al., 1995). Thus, many corporate businesses are today paying attention to the internet as valuable and available means that can be easily accessed by many different stakeholder groups (Brammer and Pavelin, 2006; Yusoff and Lehman, 2006).

More recently, with the breadth of using internet technology of reporting sustainability initiatives, many organisations have realized the importance of utilizing their websites as an important way to help them to show themselves as accountable parties within their communities (Samy et al., 2010). As such, corporate sustainability initiatives have gradually begun to appear on their websites, as a quick means help them to expand their communication with unlimited number of potential and existing stakeholders (Meyer and Kirby, 2010).

Corporate sustainability reporting, in the periods of 2000s, was also marked by international recognition especially in developed countries. Establishing several global standards on the disclosure of corporate non-financial practices was critical step in the development of sustainability reporting (Boynton, 2013). For example, the Global Reporting Initiative (GRI) is established, in 2002, as guidelines for reporting on the economic, environmental and social dimensions of business activities (IISD, 2002). It is opined that the GRI is regarded as the world's largest voluntary corporate sustainability initiative (Cetindamar and Husoy, 2007). In an evolutionary pattern similar to GRI guideline, The Dow Jones (DJ) sustainability index is launched, in the 2000, as an important voluntary tool that can be employed by organization to provide guidance for its external stakeholders looking for profitable companies that follow sustainable development principles. This international index also helps companies in reporting their sustainability performance as a means to keep the stakeholders informed of their sustainable activities (Depraz et al., 2004).

The paths to sustainable practices have become substantially clearer in the recent years. Corporate sustainability practices, in most Western countries, have witnessed a remarkable transformation in the way sustainability in the expectations of an organization's sustainability performance and its disclosure strategy (Stewart, 2015). Consequently, corporate businesses believe that maintaining a good and cohesive relationship with all stakeholders through voluntary initiatives are no longer the only conditions for legitimizing their existence, where creating a long-term by offering a variety of information that reflects their sustainability performances also leads to legitimize their actions (Dowling and Pfeffer, 1975). As such, corporate sustainability has evolved from the focus on promoting corporate social and environmental, social and governance (ESG) performance to more sustainability initiatives disclosures that can drive high quality financial performance (Rezaee, 2015). Thus, corporate sustainability reporting, as a global trend, has 
become an increasingly useful way of creating long-term business value, and win shareholder and stakeholder trust (BCCCCEY, 2013).

\section{Conclusions}

The purpose of this paper is to trace the conceptual evolutionary path on corporate sustainability practises and their reports. It is revealed that there have been a number of progressive shifts with regard to definition of sustainability concept throughout three phases. The first evolutionary pattern, which started on the 1950s, has witnessed a shift in focus of sustainable development notion towards the development of the worlds' natural resources. This concept has also emerged as a defining human rights issue against many negative images that embodied human's unethical actions in the world. The second evolutionary pattern, started in the 1980s, saw further expansion of the conceptual evolutionary pattern of sustainable development to engage within the business practices. The third evolutionary pattern, which started in the 2000 s, is the era of corporate sustainability reporting. This phase saw also expansion of public awareness about the importance of sustainability information in encouraging further recognition of the other stakeholder demands.

\section{References}

1. Abu-Raya, R. K. (2012) The Relationship between Corporate Governance and Environmental Disclosure: UK Evidence. PhD Thesis, Durham University, UK.

2. Adams, C. A. \& Frost, G. (2006) Accessibility \& functionality of the corporate web site: implications for sustainability reporting', Business Strategy \& the Environment, 15(4): 275-87.

3. Adams, C., Hill, Y. \& Roberts, C. (1998) Corporate Social Reporting Practices in Western Europe: Legitimaing Corporate Behaviour? The British Accounting Review, 30: 1-21.

4. Anderies, J, Folke, C., Ostrom, E, Walker, B. (2013). Aligning key concepts for global change policy: robustness, resilience, \& sustainability. Ecology and Society 18(2): 1-8.

5. Bani-Khalid, T. \& Ahmed, A, (2017). Corporate Social Responsibility (CSR): A Conceptual and Theoretical Shift, International Journal of Academic Research in Accounting, Finance and Management Sciences, 7(1), 203-212.

6. BCCCCEY (2013) Boston College Center for Corporate Citizenship \& Ernst \& Young, Value of sustainability reporting, available online: http://www.ey.com/Publication/vwLUAssets/EY_Value_of_ sustainability_reporting/\$FILE/EY-Value-of-Sustainability-Reporting.pdf

7. Boynton, J., (2013) How the Voice of the People is Driving Corporate Social Responsibility. Harvard Business Review Online at https://hbr.org/2013/07/how-the-voice-of-the-people-is JULY 17, 2013

8. Brammer, S. \& Pavelin, S. (2004) Voluntary Social Disclosures by Large UK Companies. Business Ethics, A European Review, 13: 86-86.

9. Campopiano, G., De-Massis, A. \& Cassia, L. (2012) The Relationship Between Motivations \& Actions in Corporate Social responsibility an Exploratory Study. International Journal of Business \& Society, $13(3): 391-425$.

10.Carroll, A. (1999) Corporate Social Responsibility: Evolution of a Definitional Construct. Business \& Society, 38:268-295

11.Cetindamar, D. \& Husoy, K. (2007) Corporate Social Responsibility Practices \& Environmentally Responsible Behavior: The Case of the United Nations Global Compact. Journal of Business Ethics. 76(2):163-176.

12.Deegan, C. \& Rankin, M. (1996) Do Australian Companies Report Environmental News Objectively? An Analysis of Environmental Disclosures by Firms Prosecuted Successfully by the Environmental Protection Authority. Accounting, Auditing \& Accountability Journal. 9(2): 50-67

13.Deegan, C. (2002) Introduction: The legitimising effect of social \& environmental disclosures - a theoretical foundation. Accounting, Auditing \& Accountability Journal. 15(3): 282-311.

14.Deegan, C. M. (2007) financial accounting theory. 2nd ed. Australia: McGraw-Hill.

15.Depraz, S. et al. (2004). Global sustainability reporting practices \& trends in the oil \& gas industry A survey. In: International Conference on Health, Safety \& Environment in Oil \& Gas Exploration \& 
Production Held in Calgary, Alberta, Canada., 29-31 March 2004. USA: International Society of Petroleum Engineers, pp.1-5.

16.Dissanayake, D., Tilt, C. \& Xydias-Lobo M. (2016) Sustainability reporting by publicly listed companies in Sri Lanka, Journal of Cleaner Production, 129: 169-182.

17.Dowling, J. \& Pfeffer, J. (1975) Organizational legitimacy: social values \& organizational behavior. Pacific Sociological Review. 18(1):122-136.

18.Du-Pisani; Jacobus, A. (2006) Sustainable development- historical roots of the concept, Environmental Sciences. 3(2):83-96.

19.Fisher, J., \& Rucki, K. (2016) Re-conceptualizing the Science of Sustainability: A Dynamical Systems Approach to Understanding the Nexus of Conflict, Development \& the Environment. Sustainable Development, Published online in Wiley Online Library, doi: 10.1002/sd.1656.

20.Gray, R. \& Bebbington, K. (2001) Accounting for the environment. 2nd ed. London: Sage.

21.Gray, R. \& Kouhy, R. (1993) Accounting for the environment \& sustainability in lesser developed countries: An-exploratory note. Research in Third World Accounting. 2: 387-399.

22.Gray, R., Kouhy, R. \& Lavers, S. (1995) Corporate Social \& Environmental Reporting: A Review of the Literature \& a Longitudinal Study of UK Disclosure. Accounting, Auditing \& Accountability Journal, 8, 4777.

23.Gudmundsson, H., Hall, R., Marsden, G., \& Zietsman, J. (2016) Sustainable Transportation, Springer Texts in Business \& Economics, Springer Heidelberg New York

24. Hackston, D. \& Milne, M. (1996) Some Determinants of Social \& Environmental Disclosures in New Zealand Companies. Accounting, Auditing \& Accountability Journal, 9, 77-108.

25. Harris, J. (2000) Basic Principles of Sustainable Development

26. Herzig, C. \& Godemann, J. (2010) Internet-supported sustainability reporting: developments in Germany, Management Research Review, 33 (11):1064-1082

27. Hopwood, B., Mellor, M., \& O’Brien, G. (2005). Sustainable development: Mapping different approaches. Sustainable Development, 13,(1):38-52. doi:10.1002/sd.244

28.IISD (2012) International Institute for Sustainable Development, SD Timeline, an online report for Sustainable Development, Available online at: http://www.iisd.org/pdf/2012/sd_timeline_2012.pdf

29.Jenkins, H. \& Yakovleva, N. (2006). Corporate social responsibility in the mining industry: Exploring trends in social \& environmental disclosures. Journal of Cleaner Production.14(3-4):271-284

30.Meyer, C., \& Kirby, J (2010) the Big Idea: Leadership in the Age of Transparency, Harvard Business Review, 88(4):38-46.

31.O'Dwyer, B., Unerman, J., Bradley, J. (2005) Perceptions on the emergence \& future development of corporate social disclosure in Ireland: Engaging the voices of non-governmental organisations, Accounting, Auditing \& Accountability Journal, 18 (1):14-43.

32.Paul, B. (2008). A History of the Concept of Sustainable Development: Literature Review, Annals of the University of Oradea, Economic Science Series. 2008, 17 (2):581-585.

33.Pearce, A. (1999) The Science \& Engineering of Sustainability: A Primer, Technical paper produced for the Institute of Sustainable Technology \& Development, Georgia Institute of Technology, Atlanta, GA. Available at: http://maven.gtri.gatech.edu/sfi/resources/pdf/TR/TR018.PDF

34.Porter, M. \& Linde, C. (1995). Toward a new conception of the environment-competitiveness relationship. Journal of Economic Perspectives, 9(4):97-118.

35.Rezaee, Z. (2017) Corporate Sustainability: Theoretical \& Integrated Strategic Imperative \& Pragmatic Approach, The Journal of Business Inquiry, 16 (1):60-87.

36. Roberts D.H., Koeplin J.P. (2007). Sustainability reporting practices in Portugal: Greenwashing or triple bottom line. International Business \& Economics Research Journal, 6(9): 29-40

37.Samy, M. Odemilin, G., \& Bampton, R. (2010). Corporate social responsibility: a strategy for sustainable business success. An analysis of 20 selected British companies, Corporate Governance: The international journal of business in society, 10 (2) :203-217.

38.Stewart, J. (2015) The Routledge Companion to Financial Accounting Theory, Routledge, 2015. 
International Journal of Academic Research in Accounting, Finance and Management Sciences Vol. 9 (3), pp. 17-23, @ 2019 HRMARS (www.hrmars.com)

39.WECD (1987) The world commission on environment \& development: Our Common Future. New York: Oxford University Press for the Brundtland Commission. available online at: http://netzwerkn.org/wp-content/uploads/2017/04/0_Brundtland_Report-1987-Our_Common_Future.pdf 